\title{
A Pink Writing Experiment
}

Teija Löytönen, Doctor of Arts, Aalto University School of Arts, Design and Architecture, Finland (corresponding author) email: teija.loytonen@aalto.fi

Mirka Koro-Ljungberg, PhD, Arizona State University Mary Lou Fulton Teachers College, USA

David Carlson, PhD, Arizona State University Mary Lou Fulton Teachers College, USA

Amy Orange, PhD, University of Houston-Clear Lake School of Education, USA

Joshua Cruz, MA, Arizona State University Mary Lou Fulton Teachers College, USA

\begin{abstract}
This article addresses a collaborative writing experiment that explores spaces of diverse encounters that began at a research conference held in the Flamingo hotel in Las Vegas; spaces where knowings emerge in the (shared) moment, in-between (our)selves, prompted by different (research) questions and entanglements of matter and meaning. Through these multiple and emergent writing encounters we explore ways towards collaborative scholarly writing and accessible ways of working and knowing beyond the immediately known or sensed. In addition, this collaborative writing experiment serves to inspire and engage participants (qualitative researchers and ethnographers alike) to explore, share, and disseminate knowledge across contexts differently. We call for writing in qualitative research that senses, figures out, and "reveals" via moving and sensuous bodies, and emerging embodied encounters within particular spaces.
\end{abstract}

Key words: Collaborative writing, pink experiment, embodied encounters, emerging qualitative scholarship, Deleuze

\section{Locating writing experiments and meeting pink flamingos}

Recent movements toward post-qualitative research call for different forms and conceptualizations of scholarly writing that are responsive to diverse ways of thinking/knowing and practicing qualitative research in various contexts (see e.g., Lather \& St. Pierre, 2013; St.Pierre, 2011). Writing beyond (simplistic) description and 'writing beyond writing' are, however, challenging and always somewhat unfinished and incomplete tasks. Furthermore, many practices associated with qualitative inquiry are (still) heavily sedimented in linear, cleaned and purified, and often single-authored modes of communicating about scholarly thoughts and 'representing' the world. Writing as a method of inquiry, as a mode of (messy) encounters with the world, and as a mode of collaborative (fluid and entangled) joint efforts, has been emerging within qualitative research texts, books, and articles for some time now (see e.g., Lather, 2010; Koro-Ljungberg \& MacLure, 2013; Richardson \& St. Pierre, 2005) yet many writing practices illustrated in conferences, journals, and diverse academic contexts are quite normative and less experimental in their forms and approaches. It is quite different to 'talk about writing' differently than 'do it' differently. Furthermore, it may also seem (im)possible to engage in 'writing 
beyond writing' yet this haunting task is prompting us to 'write' this text. This possible discrepancy between conceptualizations of writing as messy, emerging, and experimental and rather normative actualizations of writing practices call for more examples that have potential to reconceptualize habitual ways of thinking and practicing qualitative research; and for using qualitative tools in different, more complex ways including experimental, reflective, and theoretical engagements within diverse research events. Thus, the purpose of this article is not to create understandings or describe our writing experiment per se but to bring together different entanglements, rhizomes, forces, and thoughts that might produce writing as sensed and lived in a variety of spaces and at different times. Baugh (2010) explained that for Deleuze experimentation involves interactions with the unknown without preconceptions what these interactions should be. Similarly, we began our experiment without any particular directives or plans besides writing at a shared time and space while being interested in investigating what different bodies, environments, and relations might offer and prompt in and among us.

Some exciting writing experiments associated with qualitative research have been published previously. For example, in this context we aim to extend the work of Davies and Gannon (2006), Diversi and Moreira (2009), Gale and Wyatt (2009), Wyatt, Gale, Gannon and Davies (2011) and Wyatt and Gale (2012) among the others by writing and living through in-between-ness and uncertainty, acknowledging and problematizing various gaps between living and documenting/writing about this living. The writings of previously mentioned authors, often inspired by Deleuze-Guattarian concepts, such as the rhizome, becoming, in-between-ness, zigzagging, and the assemblage, also challenge the orthodoxies of qualitative writing and research reporting that is sometimes represented as disembodied and written from nowhere, without any gaps between the world and its representation or without considering the problematics of representation or writing itself especially in collaborative projects. Gale and Wyatt (2012) note that "with Deleuze, it is a starting in the middle; a thinking, feeling and sensing into futures, a writing into an always not yet known...and then, of course, always something more" (p. 467). In some cases the Deleuze-Guattarian concepts might move qualitative researchers towards more emergent and creative writing practices; toward writings that emerge in between the (two or more) authors engaging in thinking and 'becoming authors' at a shared time and space. For example, the Deleuze-Guattarian figure of the rhizome can serve as a helpful image to inspire qualitative researchers in creating (new) emergent writing spaces:

"A rhizome has no beginning or end; it is always in the middle, between things, interbeing, intermezzo. The tree is filiation, but the rhizome is alliance, uniquely alliance. The tree imposes the verb "to be" but the fabric of the rhizome is the conjunction, "and...and...and..." (Deleuze \& Guattari, 1987 , p. 25, italics in original).

Similar to the text in this article, the rhizome has "multiple entryways" and "it operates by variation, expansion, conquest, capture, offshoots" (Deleuze \& Guattari, 1987, p. 21). What follows in this context is a series of writing events and writing entryways produced through in-between-ness, variations, expansions and offshoots. Similar to a Deleuzian experiment, the series of writings in this article operate in medias res; as in quite literally, in the middle of things. These kind of writing processes resemble a kind of zigzagging, unfolding movement between the writers creating always different assemblages of percepts and affects, thoughts and feelings, senses, connections, and theoretical (re)conceptualizations within diverse research events and encounters. Our zigzag movement produced one type of assemblage (arrangement and coming togetherness) similar to this collective and emerging writing experiment at a research conference held in the Flamingo hotel in Las Vegas, Nevada. Different forces that produced writing and text come together in this illustration. 
It is important to note that this article neither tries nor could it ever capture or represent the totality of our experiences as a writing collaborative in Las Vegas and beyond the conference in our offices, hiking trails, coffee shops, homes and so on. Instead, it more than likely fails quite miserably as a representation of our time together at the conference and in Las Vegas. Baugh (2010) reminds us that experimentation within a Deleuzian framework calls for patience and prudence especially since "certain combinations may be destructive to the experimenter and to other" (p.94). Thus, through patience and sense of unplanned 'living' we hope to inspire readers to begin their own writing experiments in alternative spaces. It might be possible that an experiment proceeds bit by bit using different techniques and materials within different circumstances while breaking free from past assemblages (i.e., what does it take to attend a conference, a session, or a writing experiment, what to do in Las Vegas, how to use pink flamingos). Writing and assemblages remain in motion; time-bound and in medias res. It is also possible that our experiment prompts 'nothingness' which, in turn, can potentially create new possibilities for absent-present-experiments in the very near and distant futures.

Deleuze and Guattari (1994) proposed that, "to think is to experiment, but experimentation is always that which is in the process of coming about - the new, remarkable, and interesting" (p.111). Following Deleuze and Guattari this writing experiment also challenges qualitative researchers to practice new, creative, spontaneous, and mysterious writing; writing that is difficult to predict and externally control. Perhaps qualitative researchers could do more scholarly writing experiments that extends and challenges rather than confirms or systematically builds normalizing and sedimentary regimes. By experimenting (with) writing processes this project also problematizes what qualitative research writing might be(come) especially through the connections that are formed, and through what actualizes in these multifaceted connections. Following Deleuze and Guattari (1987) we throw ourselves into this experiment assuming the risks and pitfalls it engenders. Rather than (only) proclaim or describe it, we resist the temptation to offer any specific descriptions for experimentations. Thus this project follows their urge to:

"Lodge yourself on a stratum, experiment with the opportunities it offers, find an advantageous place on it, find potential movements of deterritorialization, possible lines of flight, experience them, produce flow conjunctions here and there, try out continuums of intensities segment by segment, have a small plot of new land at all times...Connect, conjugate, continue: a whole "diagram" as opposed to still signifying and subjective programs." (Deleuze \& Guattari, 1987, p. 161)

Furthermore, inspired by Deleuze (Deleuze, 2004; Deleuze \& Parnet, 2002) we rely on (smooth) spaces of encounters, spaces where writing is a mode of inquiry (Richardson \& St. Pierre 2005) and where knowing emerges in the moment, in connections and in-between spaces and places. Through these multiple and always-emergent encounters scholars may seek to disrupt their usual modes of writing qualitative inquiry and habitual sense of the ways research/inquiry are/ought to be practiced or disseminated. Scholars may look within the crevices of their own work, of their own ideas, to follow along unknown and unpredictable trails, or unfoldings within their own scholarly questions. With various experiments scholars could also become increasingly aware that knowing and knowledge continually evolve through the flows and intensities of diverse encounters within this 'thisness', virtual presence, and haeccities. Knowing and knowledge are indeed bodily or corporeal experiences that involve the ineffable. They are contextualized and unpredictable experiences par excellence.

In line with Baudrillard (2003) words for us are generators of ideas, weavers of spells and magic. Words 
pass and transport ideas by metabolizing ideas and objects into spiral evolutions. This collective writing gets its energy from departures and it operates through surprise, movement, and the unexpected (see also Massumi, 2002). Collaborative writing is not peaceful, univocal, or textual but writing without a plan happens, is cacophonous, and is brimming with surprises. Scholars may think through difference and continuous new beginnings every time they add or remove text from these pages. This writing experiment in the Flamingo hotel in Las Vegas does not carry "truth(s)" or represent ontologies of sameness. Sameness (if it does exist) operates within confluences of differences, to the extent that one is not privileged over the other. Instead, drawing from the Deleuzian ontology of difference (Deleuze, 2004) we articulate what actualizes of the multiple virtual intensities, the folding, unfolding and refolding of difference, in these particular socio-material encounters and how these remind us about connections with qualitative research practices. These connections, these emergent encounters might open new possibilities to do, think and write qualitative research; to do the sayable, thinkable, knowable, and desirable in multiple venues, across time/spaces. Qualitative research is not detached from space or scholars'/individuals' encounters but thinking about and doing research emerges with/in our relationships and meetings with others and material with/in spaces and places.

More specifically, this collaborative writing experiment began in our conference presentation with an invitation to the conference session participants. Altogether five session participants accepted our invitation and took part in this collaborative writing experiment during and after the conference along the two session organizers. However, beyond this invitation the following "doings" and encounters emerged spontaneously, in an unanticipated and unexpected manner. Later, immediately after the conference, participants' writings and contributions were assembled, jointed by the session organizers and distributed (back) to the participants. Existing writings were extended and elaborated via e-mail exchanges and face-to-face conversations. Texts, images, and affects were created in hotel rooms, lobbies, cars, offices, homes, outdoors, alone and in collaboration.

The following is a multilayered assemblage of the emergent encounters as lived up to this moment. We explore and experiment with writing not to reject other forms of qualitative or ethnographic writing but instead to embrace them, blend them, to widen thought about what might become possible, to see what happens from these encounters with/in the multiple spaces and places. In this way our writing experiment was not a stable configuration or fixed task, but it kept changing, moving, transforming, and transgressing throughout different interrelated events and collaborative extensions. Thus the following image (un)successfully maps the becoming of this (writing) experiment.

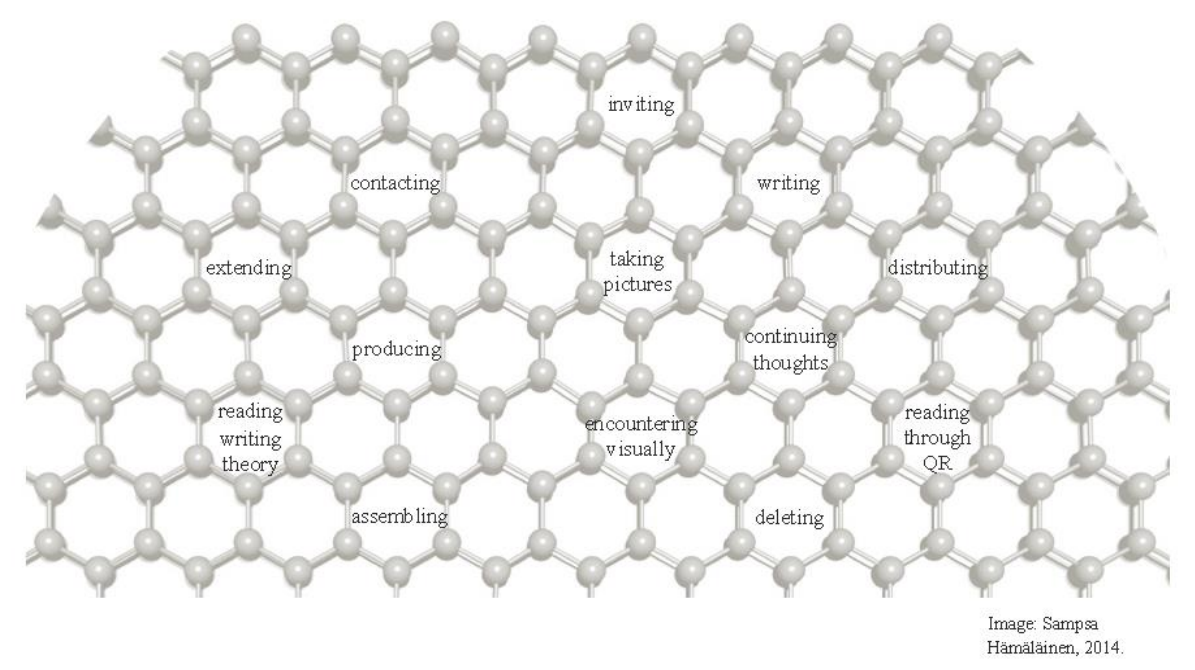


Invitation to the conference participants

We would like to invite you to join us

for an embodied writing

experimentation in and around

flamingo fotel in Las Vegas. The

aim is to collaboratively explore the

encounters within shifting environment

and changing spaces. furthermore, we

are interested in how scholars could

document these encounters and shifts.
We would like you to move with

us until something draws your

attention, grabs you, and stops

your movement. Then you could

stop and sense the space and you

within the space. Document your

senses, thinking, and writing that

might be happening within those

encounters.

The following questions might help you to reflect your encounters:

Where are you? What is happening? What is moving/changing/emerging?

What do you see/hear/ smell/ feel/sense?

How do your moves/moving/movements around the environment/spaces activate/deactivate your thinking/thoughts/writing?

Where does the embodied encounter with the space and place take you - here and now?

How can you activate the space, so as to reactivate your body and write with your body, in its many experiential dimensions?

How can a space be made to house a field of diverse embodied relations?

How do we negotiate the complicated relation of matter and meaning especially through writing?

As you move around the space you can document your embodied experimental encounters with space, for example, by writing a few lines during or after the experiment. You can also document your encounters by images, photographs, or videos. It is our goal to enable this event to unfold into an assemblage of emergent writings, which can take us (qualitative researchers) further towards unexpected intensities.

Send some or all of your documentation/production/images/sketches to Teija and Mirka by 5pm tonight. We will extend your encounters with ours and share the emergent writings with all the participants. You are also encouraged to continue and extend our encounters to build our dialogue and experimentation even further. 


\section{One and many actualized assemblage(s) of emergent writings}

In the following we articulate what actualized in these particular socio-material encounters at the research conference in the Flamingo hotel in Las Vegas (and beyond), and how these actualizations reminded us about connections with qualitative research practices. More specifically these actualizations do not form a coherent whole writing or a linear textual line to follow. Instead, they are fragmented experimentations in the process of coming about through the diverse connections. Furthermore, these connections are formed through percepts and affects, senses, conceptualizations and emerging theoretical notions, unfolding into an assemblage of emergent writings. These experimentations might also illustrate how thinking about and doing research emerges with/in encounters with others and the material with/in spaces and places.

We encourage the reader to follow the adventures, the haphazard choice of roads, the serendipitous detours, the nomadic wanderings and zigzagging lines of textual flights, as a productive experience of "getting lost" (Lather, 2007). With these multiple entryways and offshoots (none of them privileged) the aim is to unsettle, challenge and provoke qualitative research writing, and to widen thought about what might become possible, hoping to inspire readers to begin their own writing experiments.

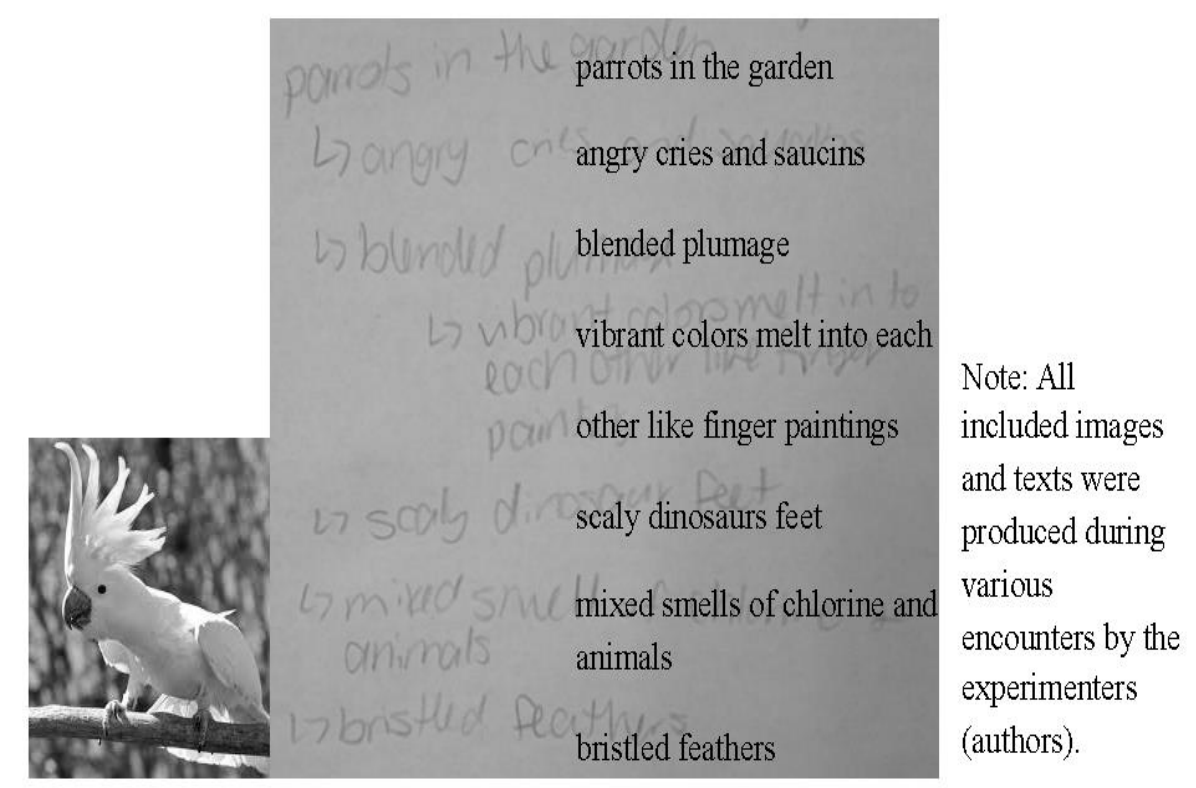

\section{One or many ethnographical nomads}

Some ethnographical scholars (also in this conference) explore foreign communities and strange environments through thick description. Foreign and strange becoming familiar through prolonged engagement, maybe to validate one's inquiry. But this place of experimentation is not a zoo or swimming pool, this is not a natural park or city landscape, this is not South America or Africa. Yet we have pink flamingos, angry parrots with bristled feathers, and golden fish among blended ethnographical research. This is a hybrid space, visitors' paradise, maybe a nomad's land. What kinds of 
spaces do we/you create for y/our qualitative research, and why, especially when you walk through nomad's land and hear parrots cry?

This space might be the carnival of fools, the Court of Miracles. A gathering of nomads and performers and colors. It is a paradox in that one feels most at home here, in this place of busquing and performing and falseness and vagrancy. The parrot's cry erupts from a mouth as a dancer with fire in a cirque du possibilité. It is where the upper crust, the richest and highest order of our society get to meet the fringe. A doc-student conference goer with a poster, the elite? Or as a performer, with aspirations of the soliel and a perpetual need to set "apart" from the rest? A pink flamingo - as a spectacle or as the very object that this space pays homage to? How does one express a way of "being" and "belonging" in Las Vegas, if not through description or explanation or sensory anything? Sometimes, one can wonder if the way to express a feeling is to simply act on that feeling. Move to Vegas, become a part of it. How can one live in a place that isn't real? A place defined by its transience and nomadism? Movements, becoming-minoritarian, becoming-parrot, becoming-pink flamingo, becoming-fringe. Perpetual transformations/transgressions, now, in Las Vegas with parrots and pink flamingos. Remembering how Todd (2005) in discussing Deleuze's philosophy reminds over and over again that, "There is always something outside our identification as subjects and persons" (p. 162, italics in original).

In-between-casino and conference space

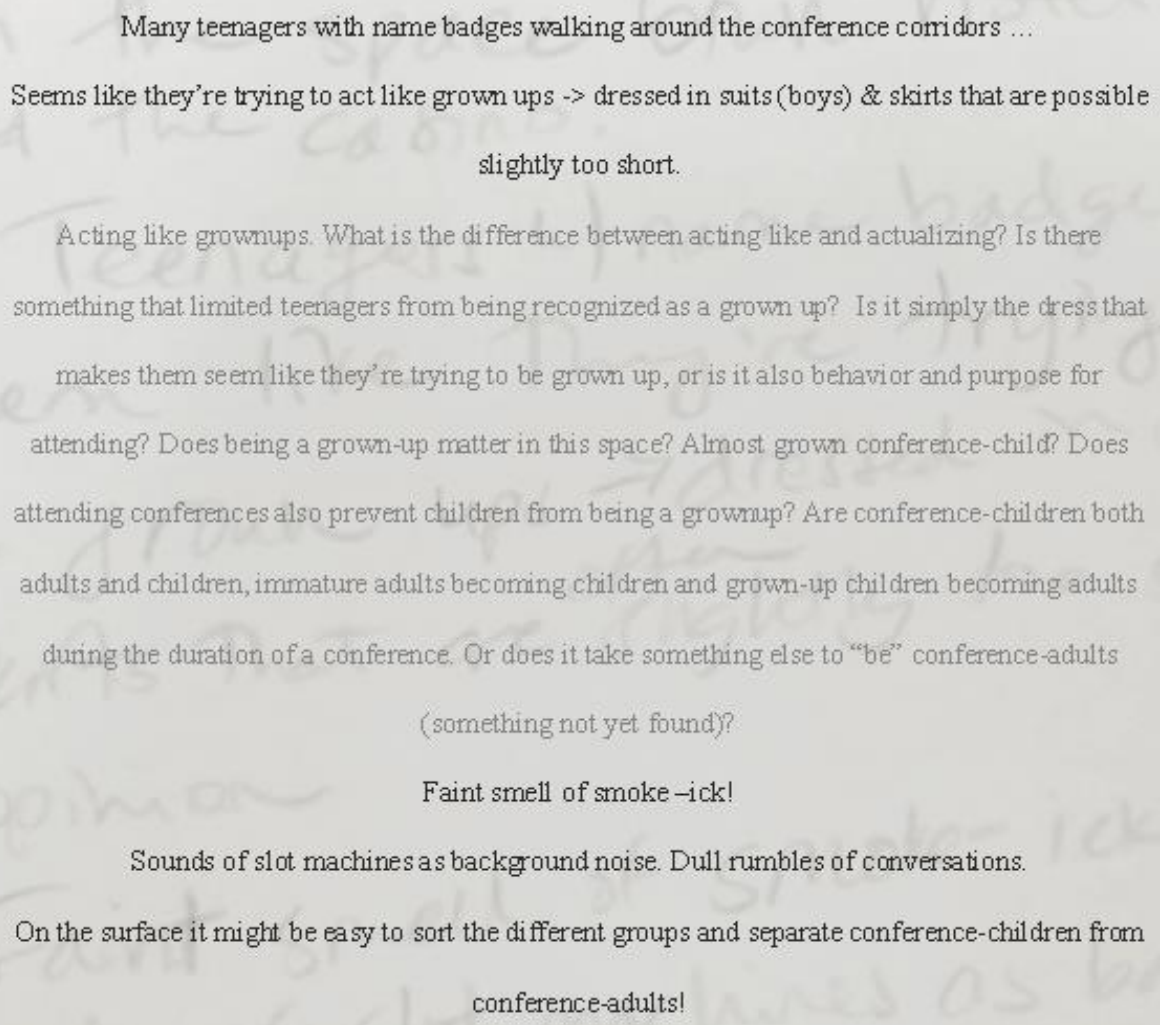


Or one might have trouble doing the sorting: if one group was a subgroup of a larger group, or if there were different conferences. Lack of certainty might make one withdraw. So many interests, so many opportunities to be interested or bored, so many potential sites of knowledge: overwhelming, stopping to care about the (perceived possible) differences in conference goers.

Casino-goers, teenager conference, our conference - how to dress?

If we looked below the surface, how much more difficult sorting and categorizing would be! Yet often in qualitative research, we strive to sort, to categorize, to look for commonalities.

What do we lose in this reduction?

Fluffy dog- what does it do here?

Feeling out of place, writing on an empty podium. Violating norms. Petting the fluffy dog.

Suitcase piled with blankets. Why?

The visuals engage me, make me ask?

Too loud to focus on conversations, which I normally lean towards.

My phone buzzing in my pocket claims me from the moment, but it can wait.

Negotiating space between home and here. Phone reminds me of this balance.

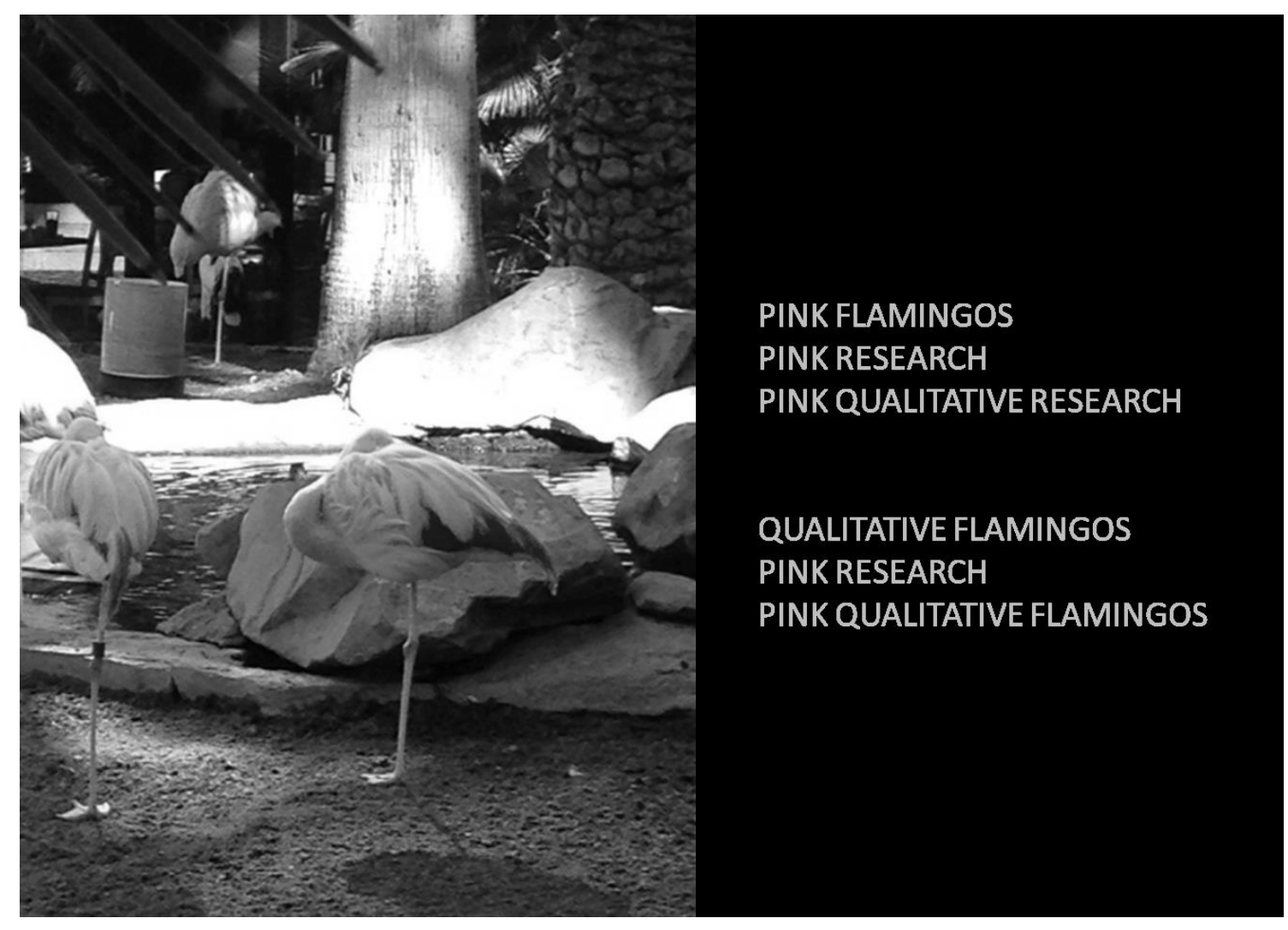

Self inspector, one-legged performer; closing oneself within oneself. Subject hides underneath oneself. No heads but only one leg and pink feathers. Enormous body weighing on one thin leg. A qualitative miracle! Are qualitative researchers wrapping oneself around oneself, producing knowledge for oneself 
and for one's own purposes? Pink flamingos move in groups and synchronize their movements collectively, opening legs and spreading their webbed foot and moving wings simultaneously. Flamingos moving-dancing finding connections and rhythm. Pink flamingos with dark shadows. Pink research with qualitative flamingos. What does qualitative do in qualitative research? Does qualitative quality focus on pinkness, moving structures, or hidden elements? Can research be pink? Colors, tastes, sounds, tactics and different senses? What do qualitative flamingos do? Think pink! Spread the Hope. Find the Cure.

Pink flamingos could symbolize qualitative researchers, serve as one (im)possible proxy for how we balance ourselves in our research and writing, between the worlds of researcher and researched and all between. As we perform at conferences, some of us shake our feathers and preen ourselves while others perch on a single leg, heads gracefully tucked close along our backs until the leg cannot hold the weight no longer.

\section{Qualitative germinator}

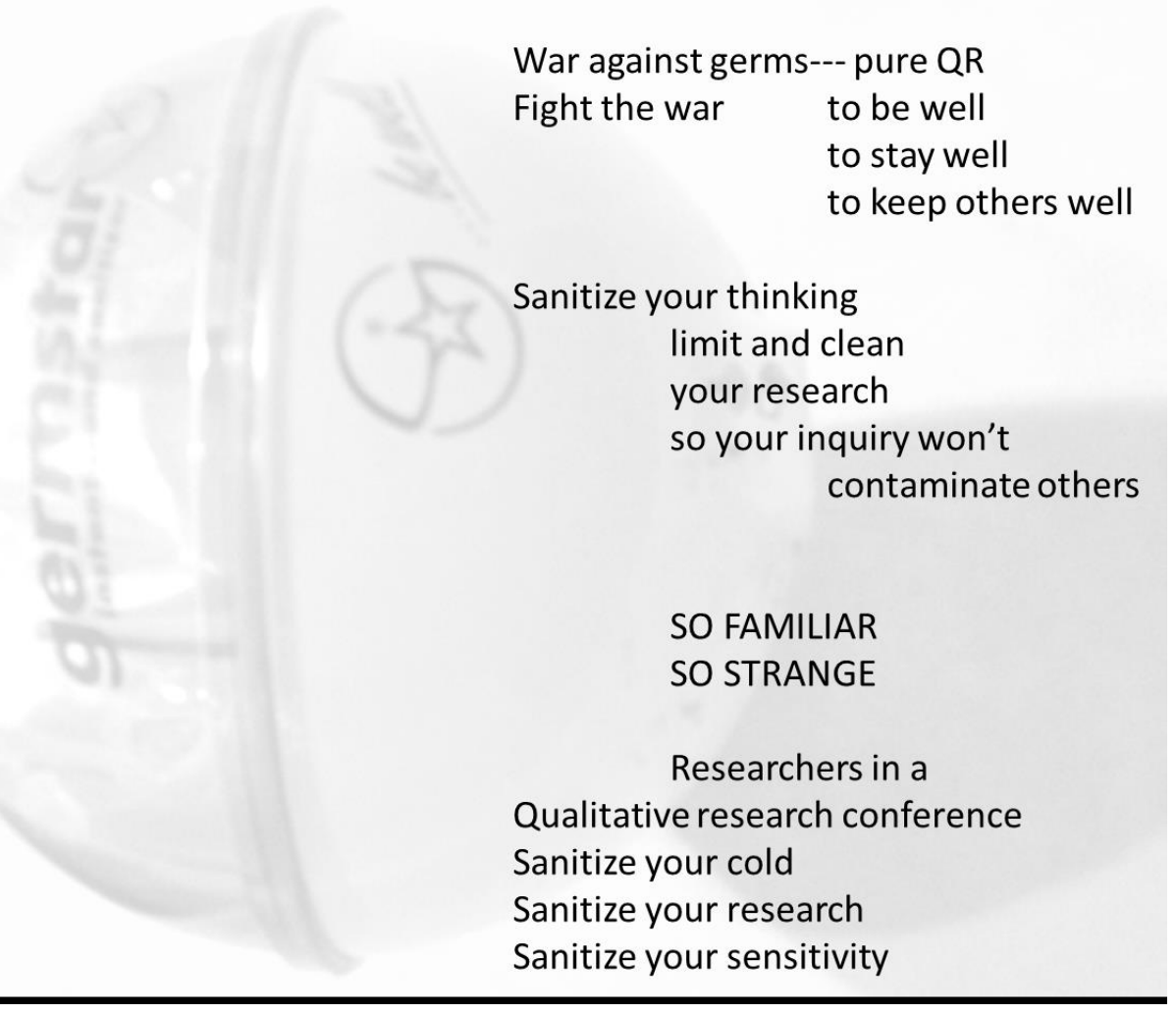

Mental hygiene. Clean thoughts, clean mind, clean bodies, clean brains produce clean research. Mental hygienists follow strict purification and sanitization processes in sterile environments. Who needs purified social science research, theories, or philosophies? Just follow rigid mental hygiene regimes produced by scienticism and institutions guided by neoliberalism. How can scholars' sensitivities be kept alive and fostered when chained down by neoliberal policies? Or is it just a random germ that takes over? Who protects us from our own sensitivities and self generated germs or is protection needed? 
And even at a scientific level, Baudrillard (2000) argues, the more an object is exposed to experimental and scientific procedures and strategies, the more it generates strategies of counterfeit, evasion, disguise, disappearance. "It is like a virus; it escapes by endlessly inventing counter strategies. This behavior of the object is also ironic insofar as it breaks the foolish pretension of the subject, its desire to impose laws and dispose the world according to its own will, its own representations. Today the world itself engages in dissidence, disobeying, in its paradoxality" (p.79). The closer scholars think they are to the object and virus the more the object distances itself ultimately becoming unreachable and undecidable. "And do not ask where it has gone. Simply, the object is what escapes the subject - more we cannot say, since our position is still that of the subject and of rational discourse" (Baudrillard, 2000, p.80). The qualitative germinator has expired.

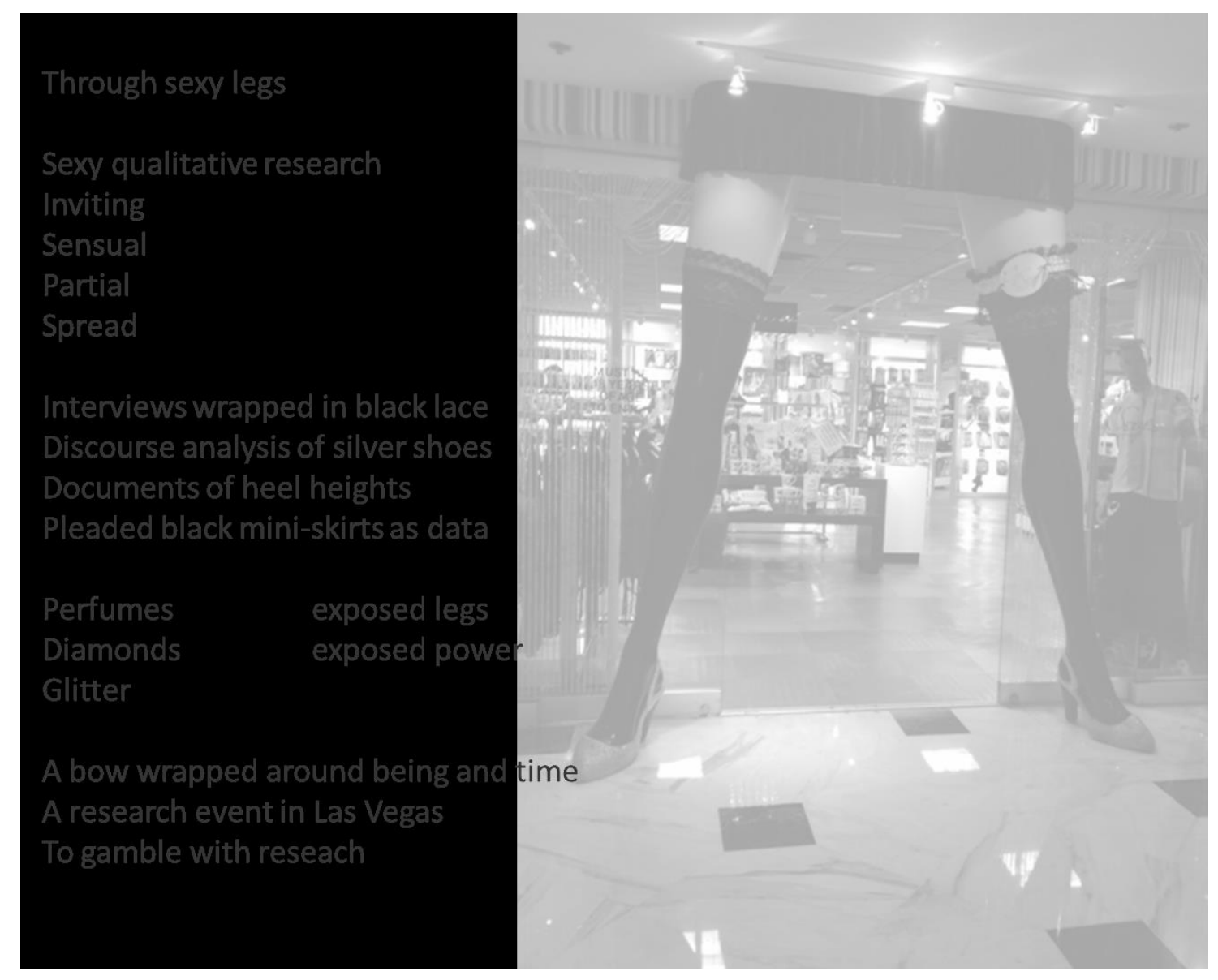

Must qualitative research come with a wow-effect? Are data and research being overproduced and reproduced to the point where nothing startles or draws attention any longer? Scholars, policymakers, bacteria, and viruses yell out: "More! We want more. We need more". Baudrillard (1983) might argue that today's Las Vegas produces and is a product of hysteria; hysteria that grounds itself into production and reproduction of real. "What society seeks through production, and overproduction, is the restoration of the real which escapes it" (p. 44). Qualitative research in Las Vegas produces signs of its own impossible copy and faces its retired resemblance. Who overproduces sexy and popular qualitative research? Who is being called upon, attracted, seduced to read and apply qualitative research and data? Do we need high silver heels and black lace to make a difference and draw attention to ontologies of difference? At the same time qualitative research is not separate from life, market forces, sexualities 
and fantasies, from lace and flesh. Qualitative research can remind us that scholarship is always material, sensed, and felt, in some ways, and connected to events and actualities of lives. Has any scholar lived to see this qualitative miracle?

\section{Working through shadows}

Experimental writing in Las Vegas also actualizes in various shadows; also shadows in us as researchers. Deleuze (1995) wrote about the importance of shadows by proposing that "once you start writing, shadows are more substantial than bodies" (p. 134). What are the shadows in our writing and in us that we recognize or not recognize as we bring them to the research process?

We have always something we do not recognize in us (our shadows) that influence our research process. In actuality we can never see our shadows but they always stay partially blur possibly only depicting the edges. Shadows are with us and they always impact the ways in which researchers' see their world and construct knowledge. Is shadow a pain, a research task, an ongoing relation with our participants and collaborators that haunts us and does not leave us alone as scholars or writers? Can those shadows permit only a sketch of knowledge? Can the sketch of writing function as violence towards the obscured body? Can histories resurrect various forms of freedom currently sheltered from the rhetoric of certainty? Which sketches or outlines of truth emerge as real, practiced, and understandable in our current simulacra?

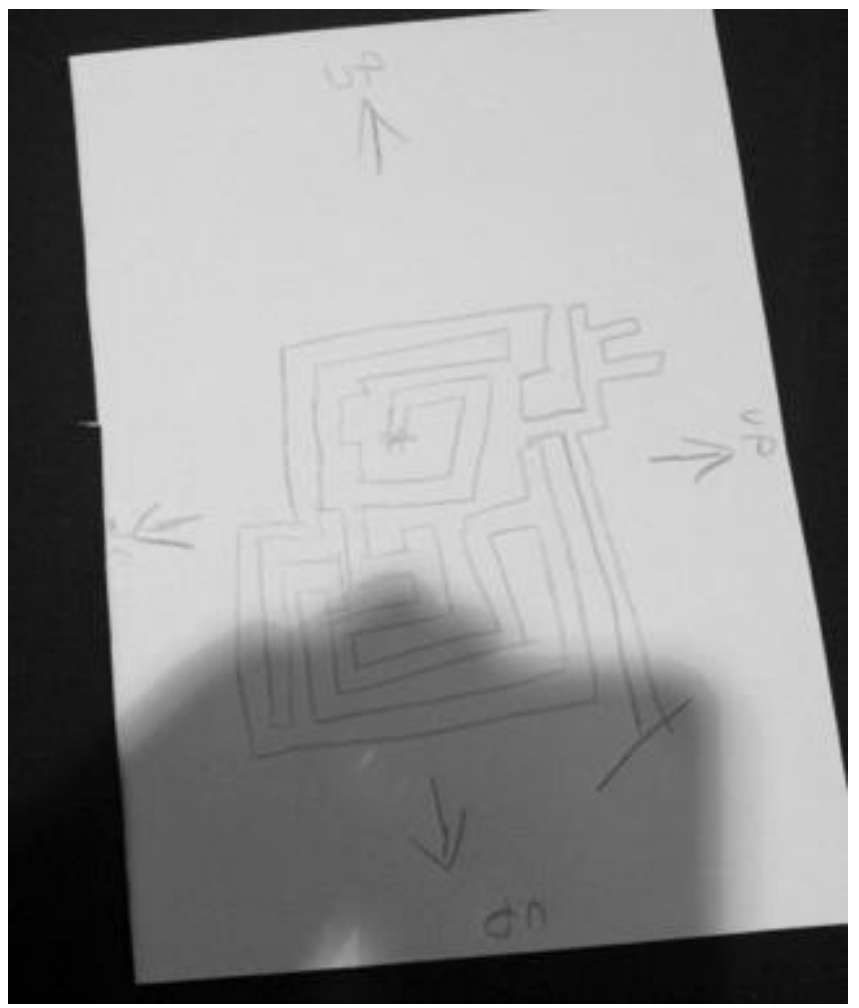


Some qualitative research methodologies and practices are closed systems and they are perceived as dogmas. At the same time scholars have desire to proceed, extend, move beyond towards other dimensions such as "up". Within closed systems that repeat practices and processes exits are blocked, invisible and seem impossible. Impossibilities continually leak out of these closed systems. Analytic frameworks that seek stability in data collection, controlling of phenomena in order to predict future outcomes veil the unending leakages of the data interactions (instead of data collection) and the embodied spaces of experiences that remain ineffable in the research processes. Thus extensions outside the system call for radical moves, breakages, and pushing forcefully through sedimented layers of existing practices. Is qualitative research in danger of creating its own too rigid boundaries and overly fixed practices as a result of forming and sustaining dualistic relationship to quantitative research?

Is qualitative research oversimplified so there's a "format" to it, a way to "Do Qual"? Students always ask for outlines showing how they "should" present their data as if there is a correct way to do it that fits every situation. They get frustrated with constant answers of, "It depends..." But it does depend — on the researcher, the data, the participants, the process, the context and on life. How do rigid boundaries fit with fluid methodologies and messy lives? 


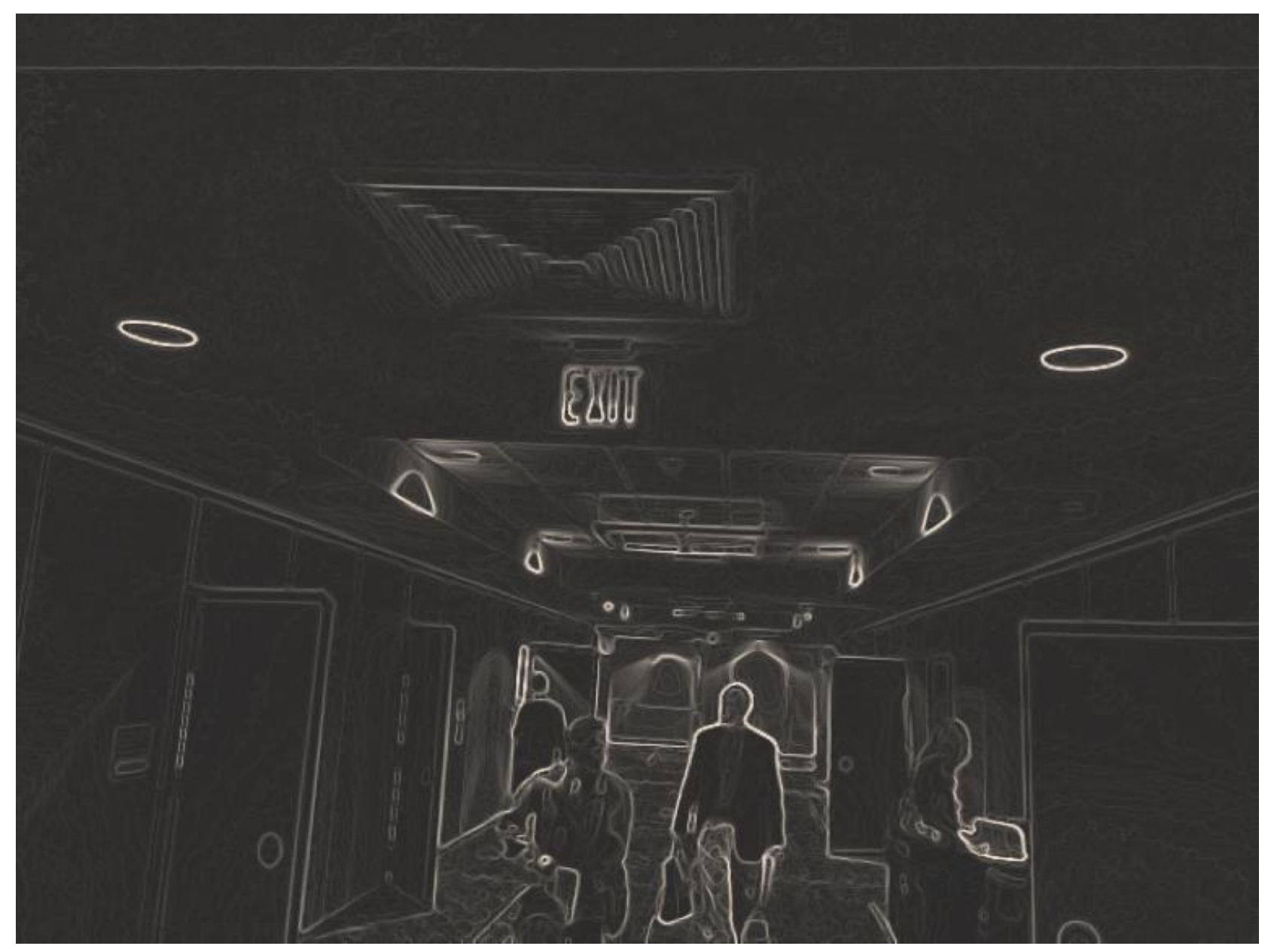

Open doors to knowledge in

rather restricted environment.

Doors leading to knowledge-

knowledge controlled, governed,

and disciplined. Knowledge produced

again and again.

Who opens and closes the doors (to knowledge)?

And to whom?

Who needs to exit?

Who needs fresh air? 


\author{
Who gets fresh air? \\ Who gives oxygen to whom? \\ Sisterhood and cultural history connects us. \\ Sisterhood without words - oxygen without molecules. \\ Who needs to leave now and see the pink flamingos?
}

\title{
Self-fashioning musical bees
}

Mess. The complexities of qualitative research can be tangible. The richness and mess of experiences, emotions, perceptions, sounds, tastes, are often represented through linear logic and through simplified forms. How can researchers make visible their complex processes and multilayered events? How might researchers think through the research process and practices as an ascesis, as a continual working on the self as they work through the many competing tensions in and through spaces as research, as they engage and interact with people, places, things, and ideas throughout the process of research (Foucault, 1997). How can we enact and assume spaces so as to fashion an on-going, ever-becoming researching self. Re-membering oneself in relation to data, interactions with others and environments. Remembering imprints, marks, traces of one's and others' work and scholarship. Re-living and reexperiencing one's value as a scholar in relation to finances, profitability, market forces, communities, and politics in and with many others. Re-membering self through the others.

Artificial, polished, fast research production. Efficient research practices and elevator speeches. Gene manipulated cows as models for qualitative research(ers). Perfection performed and sold. 'Giftwrapping' research processes hides and covers the complexities diminishing the human elements, error, mess and renders them inhumane. Success stories heard, performed, presented, and copied but not always replicated.

During conferences participants might desire connectivity, sharing and experiencing messiness of another's work. What could a conference look like if scholars would present 'stuck' stories instead of success stories? Or spontaneous stories yet untold but invented as "research"? Maybe presenters could focus on processes and failures instead of outcomes and overly sanitized and polished success stories. Conferences as contact zones for experimentations in sound, mind, and bodies in motion? Different kind of experiences. 


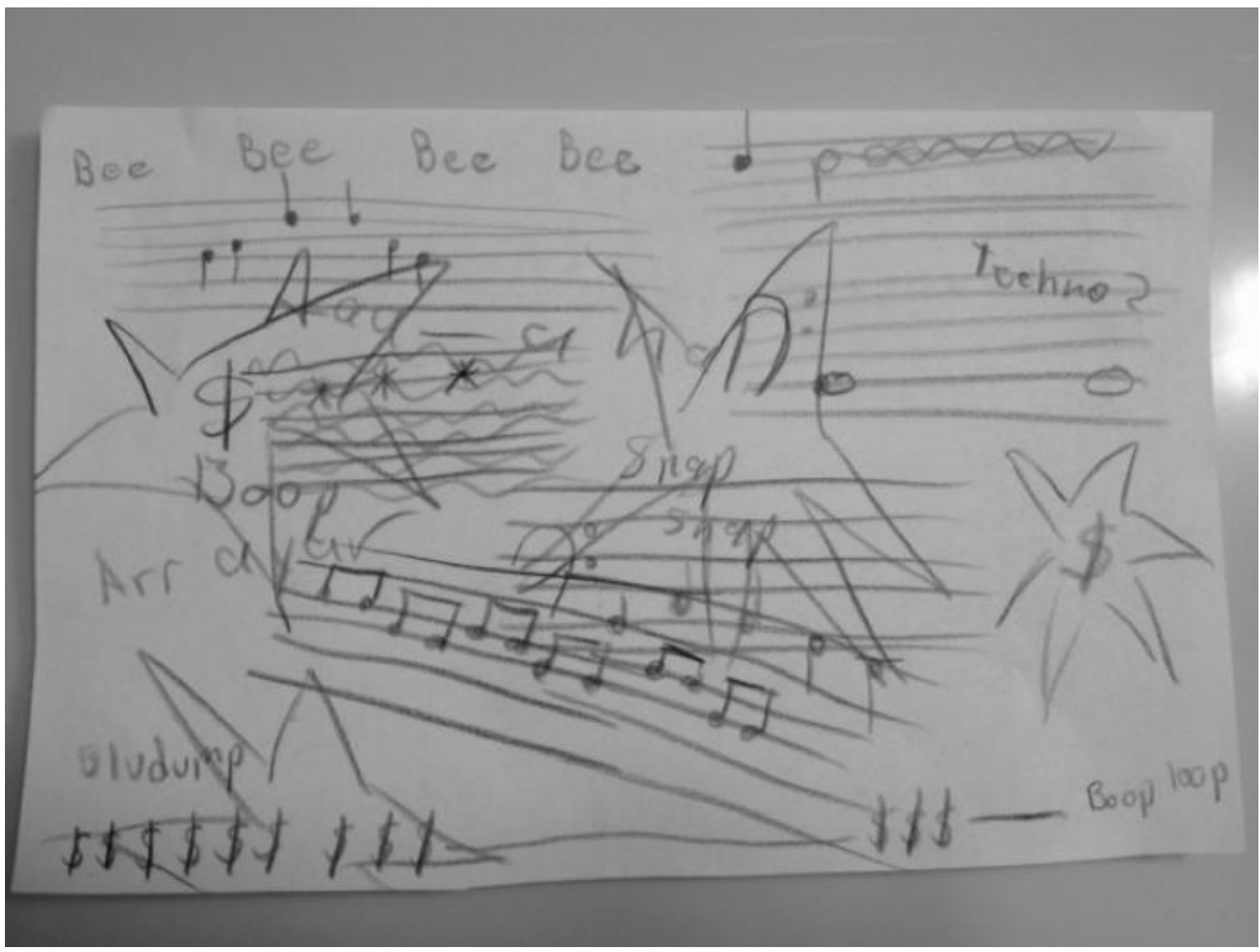

One might say that "I hear no music all I see is signs. I could think that the author is trying to represent the song being played in the environment but there is likely major disconnect between author, representation, audience and what can be heard by oneself and others. We cannot only rely on verbal markers but we could use multiple modalities. This experience echoes silence to me. My ears do not ring when I look at this image. The image is making me more present of my own situation instead of transposing the other environment. Moving and movement towards research being an event in Technicolor".

\section{Plugging in Las Vegas}

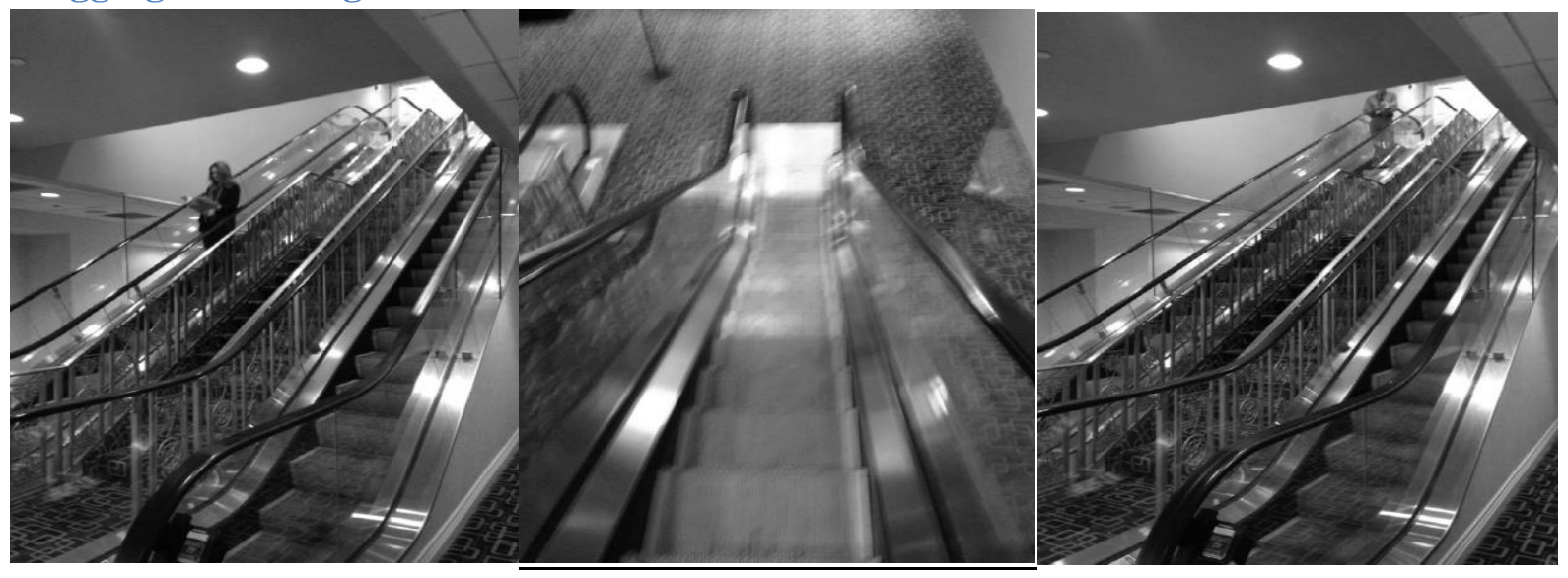


Escalators move scholars from $1^{\text {st }}$ floor to the basement, from polished tile to dirty carpet, from casino to conference rooms, from cigarette smoke to clean smell, from heated gambling excitement to cold intellectual climate. They represent the movement of science in an always/already field of chance, luck, and unlikely probabilities. They lead to "the science disseminated" in a place where scientificity collapses on itself to improbability and impossibilities, to ignorance and uncertainty. Escalators offer conference-goers the chance to experience the absurdity, the monstrosity, and futility of science. They (escalators) offer the unrealized dreams and inevitable disappointment of research's glittery giftwrapped boxes filled with knowledge and given direction. Tools and machines produce knowledge and us within them. Different parts of researchers, conference, knowledge, disjointly join and produce "thingness" and multiple tiny new beginnings and lines of flight. Moving escalators connect with researcher bodies, conference papers, carpet, bright lights, metal steps, plastic handle, qualitative research, and other machines. Moving escalators plug Las Vegas showgirls into the papers on ethnographical research producing something unexpected.

Why are we here?

What is the purpose of having a research conference in Las Vegas?

Research(ing) (in) Las Vegas, the Flamingo hotel.

Escape? The cold winter weather?

What is research in diverse spaces, locations, countries?

Is research the same everywhere, for everybody, at any time?

Spaceless - timeless - bodyless research?

How do we position our bodies in relation to research and how spaces circulate our bodies, forces our bodies to take escalators, walk through revolving doors, pay attention to pink flamingos and germinators? How much do space and bodies do research for us? What if our bodies do not function as harmonic and holistic entities but they, in their incompleteness, generate disruptions and unexpected affects and percepts? Maybe bodies both produce and divert from knowledge. Researchers' bodies disrupt the space and generate connections with other bodies, both human and non-human. Affects and percepts operate at the intra-active surfaces, and scholars' inauthenticity produce differences in research and writing. Or as Karen Barad (2007) proposes: "Phenomena [such as writing] are differential patterns of mattering ("diffraction patterns") produced through complex agential intra-actions of multiple material-discursive practices or apparatuses of bodily production" (p.140). Affects, percepts, and bodies actualize in particular spaces, where space is not a static container into which researchers are poured or "a backcloth against which action takes place, but a dynamic multiplicity that is constantly being enacted by simultaneous practices-so-far" (Fenwick, Edwards and Sawchuck, 2011, p. 11). Spatial orderings and dis-orderings, or spacings, like escalators, conference lobbies, casinos or revolving doors are actions, which are both performed and performative rather than simply existing. Spatial, material and embodied assemblages create and produce movement that interrupt and affect, question and promise singular(ities) research writing and practice? 


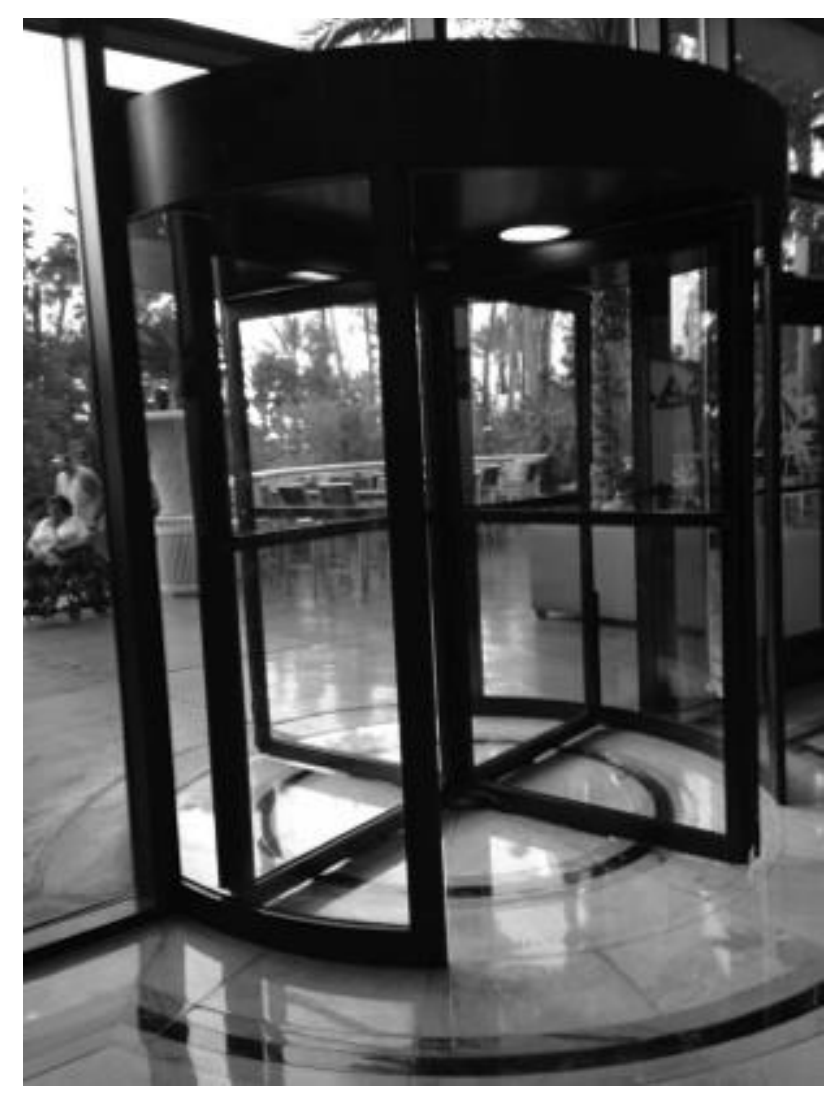

The revolving door is always closed. It turns into one direction, spaces out people through standardized compartments, pushes individuals forward until they are out, limits the number of (wo)men in the same space, allows no fresh air or birds in, keeps dirt out, and maintains even room temperature among many other things. Revolving doors do all this extremely effectively. Do we have similar logic and revolving closed doors in qualitative research? Do we offer no exit to the existential position of the dialectical of mind/body, space/non-space, in/out, and knowing/unknowing. To where might the annular exit lead? How can qualitative inquiry lead to an escape rather than toward an exit?

How do the spaces and machines work on us, perform on us, have an affect on us, and have an (unexpected) affect on research(ing)? Performative spaces, spaces for knowledge creation. Could conference spaces become events? Events for unexpected encounters?

\section{Re-visioning emerging qualitative scholarship}

Each experience, each artifact in this particular space is like a signpost that points down innumerable roads. It is the locus of and the beginning to research. The numerous possible travels involve different enactments, events, interpretations, leading to new questions instead of predictable answers and conclusions (see Koro-Ljungberg \& Barko, 2012). Sometimes scholars have a desirable destination in mind, other times we may choose a road haphazardly and start following it. We meet others along the roads, some who will give us advice, some who will steer us in a different direction, but when we finally 
seem to reach the end of one road, it is simply another confluence of other roads that we may choose one of to wander down until we reach the next intersection. These encounters in a qualitative research conference in Las Vegas do not represent or form a fixed place, but a collection of conflicting spaces, or dangerous and divergent roads to follow or not to follow.

Juxtaposition of qualitative research and Las Vegas, both dirty and clean. As qualitative researchers, we constantly negotiate by cleaning and messing up spaces, theories, inquiries, writings, participants, ourselves, and the academy. Oftentimes operating and living in the spaces between. Is it possible that the scholarly literature is so clean, purified, germ-free, formulated, and formatted that the gaps are impossible to detect? Or do we need always already closed revolving doors and endlessly moving escalators to filter, to keep out the dirtiness or to keep out the data? How do we prop the closed doors open to let it all in?

Our experiment without any particular directives or pre-meditated plans, besides various forms of writing at a shared time and space, enacts the process and production of writing differently. It strives towards reconceptualizing the linear, sanitized text of more traditional, humanist qualitative research. The writing explores the leakages that reside amongst but simultaneously erode and ooze restlessly from the complex borderlands of living and documenting/writing about that living. This writing beyond writing experiment thus gestures towards "...work which does not offer itself to anything but experimentation" (Brinkley, 1983, cited in Deleuze, Guattari \& Brinkley, 1983, p. 13).

Through this experiment we aimed to extend the diverse attempts of writing creatively within poststructuralist qualitative research. In addition to the previously mentioned authors we acknowledge other authors in their attempts to create new modes of writing practices, such as the short story or novel (Ellis, 2004), or performative components in writing (Scott-Hoy, 2002, Saldana, 2008) or embodied writing practices (Anttila, Guttorm, Löytönen, Valkeemäki, 2014; Guttorm, Löytönen, Anttila, Valkeemäki, forthcoming; Löytönen, Anttila, Guttorm, Valkeemäki, 2014). Our writing experiment hopes to advance the existing field of qualitative research writing by focusing on the intra-active relationships between the body, ideas, language, the pen, representations, theories, objects, spaces, escalators, revolving doors, movements, shadows and and and. This intra-action, inspired by Barad (2007), recognizes "the mutual constituting of entangled agencies" where the "distinct agencies do not precede, but rather emerge through, their intra-action" (p. 33, italics in original).

This experimental writing process with its multiple entryways and always new beginnings opened up an approach, as there was no time to plan what or where to observe and went in with the purpose to explore our surroundings and stretch beyond usual practices. An awareness of the self and others was maintained during this process. Balance - both sustained and disturbed. Maybe these writings pushed boundaries, making writing more open and less purified research practice. In addition, by experimenting with collaborative writing in a research conference in Las Vegas, this writing moved towards un-privileging knowledge creation to a single author/researcher. It also explored the possibilities for the creation of social spaces for qualitative researchers and ethnographers and practitioners, both inside and outside academia, and explored embodied practices through sensing, experimenting, questioning and working with differentiated perspectives. This type of collaborative writing may enable a deeper and engaged investigation of different modes of life that are affected by local histories and socio-material conditions. By focusing on movements and embodied encounters with/in spaces and places, and jointly sharing these with others in writing might open up possibilities for re-cognizing, re-membering, re-visioning emerging qualitative scholarship and future possibilities, for seeing and sensing differently through accidental encounter. 
Acknowledgements: We would like to thank Kelsey L. Merlo and Michael Shell for their initial contributions to this experiment and work. We would also like to thank the reviewers for their insightful and valuable comments and suggestions. The research work by Dr. Teija Löytönen was funded by the Academy of Finland (project number 253589).

\section{References}

Anttila, E., Guttorm, H., Löytönen, T. \& Valkeemäki, A. (2014). Happy incidents and unexpected encounters in the academia, or be(com)ing (a) present(at ion). In Arlander, A. (ed.) CARPA 3 Proceedings: The Impact of Performance as Research. Helsinki: University of the Arts \& Theatre Academy. [http://nivel.teak.fi/carpa/]

Barad, K. (2007). Meeting the Universe Halfway: Quantum Physics and the Entanglement of Matter and Meaning. Durham: Durham University Press. http://dx.doi.org/10.1215/9780822388128

Baudrillard, J. (1983). Simulations (P. Foss, P. Patton \& P. Beitchman, Trans.). United States of America: Semiotext[x].

Baudrillard, J. (2000). The Vital Illusion. Columbia University Press.

Baudrillard, J. (2003). Passwords. London: Verso.

Baugh, B. (2010). Experimentation. In A. Parr (Ed.), The Deleuze dictionary (pp. 93-95). Edinburgh, UK: Edinburgh University Press.

Davies, B. \& Gannon, S. (2006). Doing Collective Biography. Maidenhead, UK: Open University Press.

Deleuze, G. (1995). Negotiations, 1972-1990. New York: Columbia University Press.

Deleuze, G. (2004). Difference and repetition. (P. Patton, Trans.). London, New York: Continuum. (Original work published 1968.)

Deleuze, G., \& Guattari, F. (1994). What is philosophy? (H. Tomlinson \& G. Burchell, Trans.). New York: Columbia University Press.

Deleuze, G. \& Guattari, F. (1987). A Thousand Plateaus. (B. Massumi, Trans.) Minneapolis: University of Minnesota Press. (Original work published 1980.)

Deleuze, G., Guattari, F. \& Brinkley, R. (1983). What Is a Minor Literature? Mississippi Review, Vol. 11, No. 3, Essays Literary Criticism, 13-33.

Deleuze, D. \& Parnet, C. (2002). Dialogues II. (H. Tomlinson \& B. Habberjam, Trans.) London: Continuum. (Original work published 1977.)

Diversi, M. \& Moreira, C. (2009). Betweener talk: Decolonizing knowledge production, pedagogy \& praxis. Walnut Creek, CA: Left Coast Press, Inc.

Ellis, C. (2004). The Ethnographic I: A Methodological Novel about Autoethnography. Walnut Creek, CA: AltaMira Press.

Fenwick, T., Edwards, R. \& Sawchuk, P. (2011). Emerging Approaches to Educational Research. Tracing the sociomaterial. London: Routledge.

Foucault, M. (1997). Friendship as a way of life (R. Hurley and others, Trans.). In Rabinow, P. (Ed.) The essential works of Foucault, 1954-1984, Volume one, Ethics: Subjectivity and truth (pp. 135-140). New York: The New Press.

Gale, K. \& Wyatt, J (2009). Between the two: A nomadic inquiry into collaborative writing and subjectivity. Newcastle-upon-Tyne, UK: Cambridge Scholars.

Guttorm, H., Löytönen, T., Anttila, E. \& Valkeemäki, A. (forthcoming). Mo(ve)ments, Encounters, Repetitions: Writing with (embodied and textual) Encounters. Qualitative Inquiry.

Koro-Ljungberg, M. \& Barko, T. (2012). “Answers”, assemblages, and qualitative research. Qualitative Inquiry, 18 (3), 256-265. http://dx.doi.org/10.1177/1077800411431562

Koro-Ljungberg, M. \& MacLure, M. (2013). Provocations, RE-Un-Visions, Death, and Other Possibilities of "Data". Cultural Studies - Critical Methodologies. Special Issue: Data, Vol. 13, No 4, 219-222. 
Lather, P. (2007). Getting lost: Feminist practices toward a double(d) science. Albany, NY: SUNY Press.

Lather, P. (2010). Engaging science policy: from the side of the messy. New York: Peter Lang.

Lather, P., \& St. Pierre, E. A. (2013). Introduction: Post-qualitative research. International Journal of Qualitative Studies in Education, 26(6), 629-633. http://dx.doi.org/10.1080/09518398.2013.788752

Löytönen, T.; Anttila, E.; Guttorm, H.; Valkeemäki, A. (2014). Playing with patterns: Fumbling towards collaborative and embodied writing. International Journal of Qualitative Research, Vol. 7, No 2, 236257. http://dx.doi.org/10.1525/irqr.2014.7.2.236

Massumi, B. (2002). Parables for the virtual: Movement, affect, sensation. Durham, UK: Duke University Press. http://dx.doi.org/10.1215/9780822383574

May, T. (2005). Gilles Deleuze: An Introduction. Cambridge, UK: Cambridge University Press.

Richardson, L. \& St. Pierre, E. A. (2005). Writing: A method of inquiry. In N. D. Denzin \& Y. S. Lincoln (eds.) The Sage Handbook of Qualitative Research (3rd ed.). Thousand Oaks: Sage, 959-978.

Saldana, J. (2008). The Drama and Poetry of Qualitative Method. In M. Cahnmann-Taylor \& R. Siegesmund (eds.) Arts-Based Research in Education: Foundations for Practice. New York: Routledge, $220-227$.

Scott-Hoy, K. (2002). The visitor: juggling life in the grip of text. In A. P. Bochner \& C. Ellis (eds). Ethnographically Speaking: Auto-ethnography, Literature and Aesthetics. Oxford: Altamira Press, 274-294.

St.Pierre, E. (2011). Post qualitative research. In N. Denzin, \& Lincoln, Y. (Ed.), The SAGE handbook of qualitative research (4 ed., pp. 611-625). Los Angeles: Sage.

Wyatt, J., Gale, K., Gannon, S. \& Davies, B. (2011). Deleuze \& Collaborative Writing. An Immanent Plane of Composition. New York: Peter Lang.

Wyatt, J. \& Gale, K. (2012). Singularities and Multiplicities. A Preface to the Special Issue on Collaborative Writing. International Review of Qualitative Research, Vol. 5, No 4, 345-347. 